\title{
ANALISIS JENIS VEGETASI STRATA TIANG DI BUKIT SULAP KOTA LUBUKLINGGAU
}

\author{
Merti Triyanti ${ }^{1}$, Destien Atmi Arisandy ${ }^{2}$ \\ STKIP PGRI Lubuklinggau ${ }^{1,2}$ \\ mertitriyanti28@gmail.com ${ }^{1}$
}

\begin{abstract}
ABSTRAK
Tujuan penelitian ini adalah untuk mengetahui keanekaragaman jenis vegetasi strata tiang di Bukit Sulap Kota Lubuklinggau berdasarkan komposisi, kerapatan jenis vegetasidan mengetahui faktor abiotik terhadap vegetasi strata tiang di Bukit Sulap Kota Lubuklinggau. Jenis penelitian ini adalah deskriptip kuantitatif. Metode yang digunakan adalah metode jarak (Point Centered Quarter). Populasi dalam penelitian ini adalah seluruh spesies vegetasi strata tiang yang ada di dalam vegetasi Bukit Sulap Kota Lubuklinggau. Analisis yang digunakan berupa kerapatan, frekuensi, dominansi, indeks nilai penting, dan indeks keanekaragaman. Hasil penelitian, diperoleh data pada area kajian A ditemukan 16 spesies strata tiang. Pada area kajian B diperoleh 14 spesies strata tiang, Sedangkan pada area kajian C ditemukan 24 spesies strata tiang. Faktor abiotik yang terukur adalah Suhu udara di Bukit Sulap Kota Lubuklinggau berkisar $28,3^{0} \mathrm{C}-30^{\circ} \mathrm{C}$ dengan kelembaban udara $86 \%$ - 93\%. Kelembaban tanah berkisar 8 - 17 sedangkan derajat keasaman $(\mathrm{pH})$ tanah berkisar 6,3-6,7. Simpulan, rerata Indeks Nilai Penting (INP) terbesar pada strata Tiang di area kajian A,B, dan C berturut-turut adalah ketapang, belimbing, dan kopi.
\end{abstract}

Kata Kunci: analisis, vegetasi, strata tiang, bukit sulap

\section{ABSTRACT}

The purpose of this study was to determine the diversity of stratum vegetation in Sulap City, Lubuklinggau City based on composition, density of vegetation types and to know abiotic factors for stratum vegetation in Sulap Hill, Lubuklinggau City. This type of research is quantitative descriptive. The method used is the distance method (Centered Quarter Point). The population in this study were all species of stratum vegetation in the Bukit Sulap vegetation in Lubuklinggau City. The analysis used is in the form of density, frequency, dominance, important value index, and diversity index. The results of the study, obtained data in the study area A found 16 species of pole strata. In the study area B, 14 species of stratum were obtained, whereas in the study area $C, 24$ species of stratum were found. Measured abiotic factors are the air temperature in the Sulap Hill of Lubuklinggau City ranging from 28.30C - 300C with air humidity of $86 \%-93 \%$. Soil moisture ranges from 8-17 while the acidity $(\mathrm{pH})$ of the soil ranges from 6.3 to 6.7. Conclusion, the mean of the Important Value Index (INP) in the Pole strata in the areas of study $A, B$, and $C$ respectively is ketapang, starfruit, and coffee.

Keywords: analysis, vegetation, pole strata, magic hill 


\section{PENDAHULUAN}

Indonesia merupakan salah satu negara dengan keanekaragaman hayati terbesar di dunia (megabiodiversity countries) bersama dengan Brazil dan Zaire (RD Congo). Keanekaragaman hayati tersebut meliputi tumbuhan dan hewan yang tersebar di seluruh wilayah Indonesia. Indonesia menempati urutan keempat dunia untuk keanekaragaman jenis tumbuhan, yaitu memiliki kurang lebih 38.000 jenis. Keanekaragaman jenis tumbuhan tersebut tergambar pada hutan-hutan yang tersebar di seluruh kawasan Indonesia (Indrawan, 2007).

Salah satu daerah yang memiliki hutan dengan keanekaragaman jenis tumbuhan melimpah adalah Bukit Sulap Kota Lubuklinggau yang secara resmi menjadi Taman Nasional Kerinci Seblat (TNKS) sesuai dengan SK Menteri Kehutanan No.1094/Kpts-II/1996 menetapkan luas TNKS lebih kurang 1.368.000 ha. Setelah diadakan penataan batas, TNKS secara resmi ditetapkan oleh Menteri Kehutanan dan Perkebunan dengan SK No.901/Kpts-II/1999 pada bulan oktober 1999 dengan luas 1.375.349 ha. Karena itu, TNKS merupakan taman nasional pertama di Indonesia yang telah menyelesaikan semua prosedur hukum sehingga mendapat penetapan secara resmi (Kautsar, 2010).

Menurut Sunarya (2016), Bukit Sulap merupakan salah satu objek wisata alam berada dalam kawasan Taman Nasional Kerinci Seblat pada Seksi Pengelolaan Taman Nasional (SPTN) Wilayah V Provinsi Sumatera Selatan, dan termasuk dalam zona pemanfaatan pariwisata alam. Objek wisata alam ini sangat unik, yaitu akan terlihat dekat ketika memandang Bukit Sulap dan akan terlihat jauh ketika mendatangi Bukit Sulap. Hal inilah yang mendasari penamaan Bukit Sulap. Bukit Sulap yang berada di jantung kota Lubukinggau ini, selain dimanfaatkan sebagai tujuan pariwisata, juga dimanfaatkan oleh masyarakat dalam bidang lain diantaranya adalah pendidikan dan ekonomi. Hal ini terbukti dari banyaknya masyarakat yang memanfaatkan beberapa jenis tumbuhan sebagai bahan pemenuhan kebutuhan hidup yang dapat diperjual belikan, misalnya memanfaatkan kayu-kayu. Tingginya masyarakat yang memanfaatkan vegetasi di Bukit Sulap tidak diimbangi dengan pengelolaan yang baik. Sehingga, terlihat adanya beberapa kawasan yang sudah mulai rusak atau beralih fungsi. Hal ini jika dibiarkan akan mengganggu keseimbangan ekosistem di Bukit Sulap dan dapat menyebabkan hilang atau punahnya beberapa jenis vegetasi di Bukit Sulap Kota Lubuklinggau. Pada bidang pendidikan, kawasan ini menjadi lokasi penelitian/praktikum lapangan untuk beberapa sekolah.

Vegetasi yang ditemukan di Bukit Sulap Kota Lubuklinggau diantaranya adalah pohon, semak, dan herba yang memiliki banyak keanekaragaman jenisnya. Namun jenis vegetasi yang berada Bukit Sulap Kota Lubuklinggau belum pernah ada yang mendata secara terperinci. Sehingga masyarakat Kota Lubuklinggau belum mengetahui jenis vegetasi apa saja yang berada di Bukit Sulap beserta nama latin dari vegetasi tersebut, kemelimpahan jenis dan keanekaragaman jenis vegetasi di Bukit Sulap Kota Lubuklinggau, serta peranannya bagi lingkungan. 
Hal ini menyebabkan belum diketahui jenis vegetasi apa yang memiliki kemelimpahan jenis dan keanekaragaman jenis yang paling tinggi di Bukit Sulap Kota Lubuklinggau. Hidayati (2010) menjelaskan bahwa vegetasi memiliki peranan yang sangat penting dalam komunitas hutan dan berfungsi sebagai penyangga kehidupan, baik dalam mencegah erosi, maupun menjaga stabilitas iklim global. Berdasarkan pernyataan tersebut, maka peneliti tertarik melakukan penelitian dengan judul Keanekaragaman Jenis Vegetasi Di Bukit Sulap Kota Lubuklinggau.

\section{METODE PENELITIAN}

Jenis penelitian ini adalah deskriptif. Menurut Arikunto (2010), penelitian deskriptif adalah penelitian yang dimaksudkan untuk menyelidiki keadaan, kondisi atau hal-hal yang sudah disebutkan, yang hasilnya dipaparkan dalam bentuk laporan penelitian. Data yang diambil dalam penelitian ini adalah data yang diperolah melalui observasi langsung di Bukit Sulap Kota Lubuklinggau. Penelitian dilaksanakan pada bulan Desember 2016 sampai Maret 2017 di kawasan Bukit Sulap Kota Lubuklinggau. Observasi pendahuluan untuk menentukan batas-batas area kajian yang akan digunakan untuk penelitian di Bukit Sulap Kota Lubuklinggau. Berdasarkan observasi yang telah dilaksanakan, selanjutnya menghitung luas wilayah yang akan di teliti, yaitu luas keseluruhan bukit sulap 290 Ha dikurang 42 Ha untuk parawisata sehingga luas Bukit Sulap $248 \mathrm{Ha}$. Jumlah dari $248 \mathrm{Ha}$ di ambil 20\% sehingga luas area kajian adalah 49,6 Ha, masing-masing luas dari 3 area kajian A, B, dan C yang akan di amati seluas $16,5 \mathrm{Ha}=165.000 \mathrm{~m}^{2}$.

Selanjutnya menentukan setiap area kajian dibuat 10 stand, yaitu area kajian A stand 1-10, area kajian B 1-10, area kajian C 1-10 yang menjadi objek untuk dianalisis masing-masing stand memiliki $16.500 \mathrm{~m}^{2}$. Dengan menggunakan metode Point Center Quater (PCQ), setiap stand dibuat garis transek utama sepanjang $165 \mathrm{~m}$, kemudian dibuat garis sub transek yang memotong garis transek utama yang berjarak masing-masing 16,5 m. Mencatat nama tumbuhan yang ditemukan.Kemudian, mengisi tabel pengamatan yang telah dibuat, mengukur faktor lingkungan pada masing-masing stand yang meliputi suhu tanah, suhu udara, kelembaban udara, $\mathrm{pH}$ tanah. Parameter yang diamati adalah:

Rata-rata Jarak (D)

$$
=\frac{\text { Total jarak }}{4 \text { X Jumlah tit ik sampling }}
$$

Densitas Mutlak (DT) $=\quad \frac{\text { Unit area }}{(\text { rata }- \text { rata jarak })^{2}}$

Selanjutnya dihitung karakter komunitas yang meliputi: 


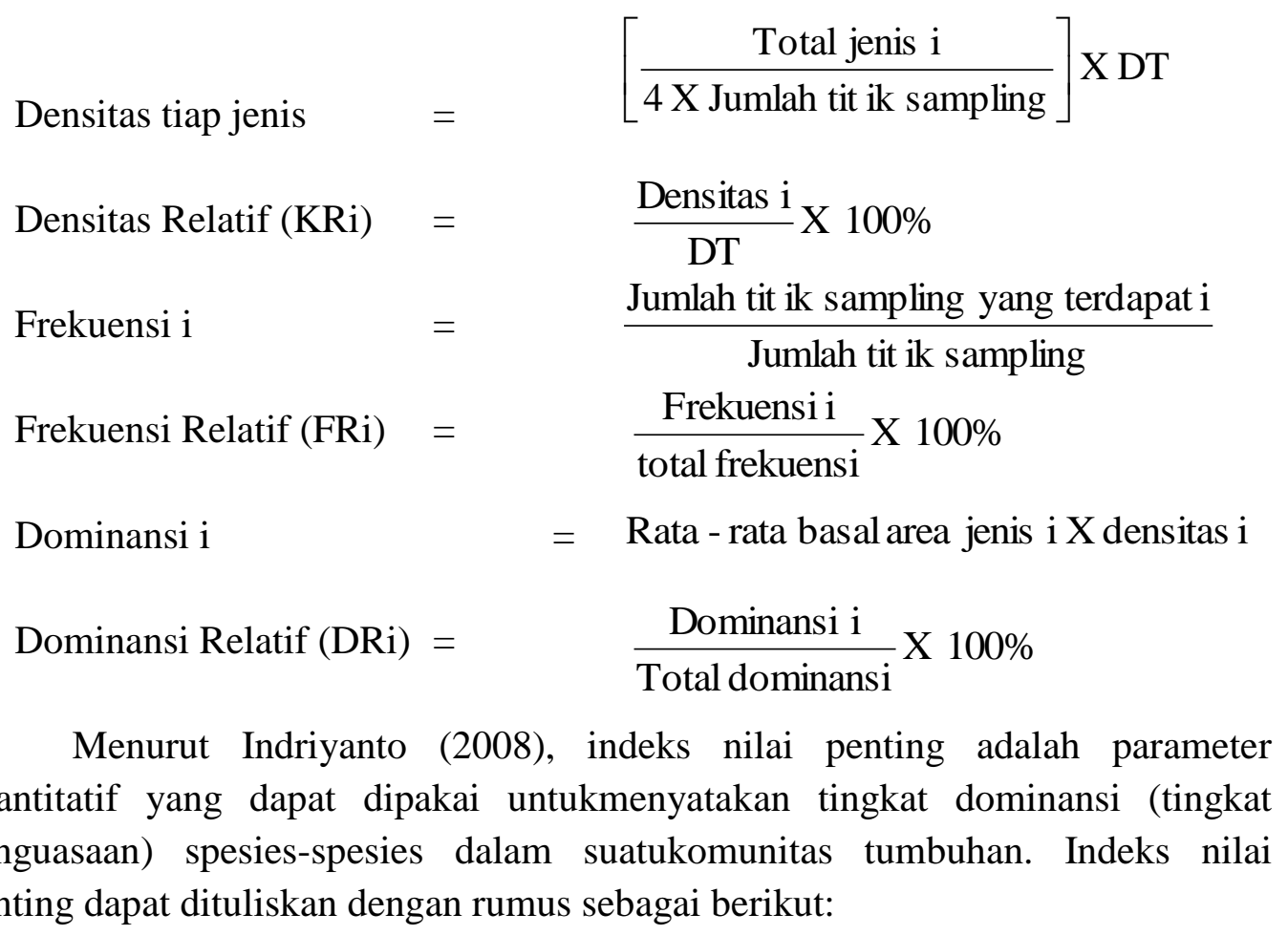

\section{$\mathrm{INP}=\mathrm{KRi}+\mathrm{FRi}+\mathrm{DRi}$}

Keterangan :

INP $=$ indek nilai penting

$\mathrm{FRi}=$ frekuensi relatif

$\mathrm{KRi}=$ kerapatan relatif

$\mathrm{DRi}=$ dominansi relatif

Keanekaragaman Shanon-Wiener(Indeks Diversitas)

Perhitungan keanekaragaman spesies diperoleh dari rumus Indeks Shannon (Indriyanto, 2008) sebagai berikut:

$$
\mathrm{H}^{\prime}=-\Sigma\{(\mathrm{ni} / \mathrm{N}) \ln (\mathrm{ni} / \mathrm{N})\}
$$

Keterangan :

$\mathrm{H}^{\prime}=$ indeks keanekaragaman shannon

$\mathrm{Ni}=$ nilai penting dari spesies ke-i

$\mathrm{N}=$ jumlah seluruh spesies pohon.

Indeks keanekaragaman merupakan parameter vegetasi yang sangat berguna untuk membandingkan berbagai komunitas tumbuhan, untuk mempelajari pengaruh gangguan faktor-faktor lingkungan atau abiotik terhadap komunitas dan 
mengetahui keadaan suksesi atau stabilitas komunitas. Besarnya Indeks Keanekaragaman $\left(\mathrm{H}^{\prime}\right)$ jenis menurut Shannon-Wiener dapat dilihat pada tabel 1 berikut:

Tabel 1. Nilai Indeks Keanekaragaman (H')

\begin{tabular}{ccl}
\hline No & Nilai & \multicolumn{1}{c}{ Keterangan } \\
\hline 1. & $\mathrm{H}^{\prime}>3$ & Melimpah tinggi \\
2. & $\mathrm{H}^{\prime} 1 \leq \mathrm{H}^{\prime} \leq 3$ & Sedang melimpah \\
3. & $\mathrm{H}^{\prime}<1$ & Sedikit atau rendah \\
\hline
\end{tabular}

(Sumber: Fachrul, 2012)

\section{HASIL PENELITIAN}

Penelitian ini telah dilaksanakan di Bukit Sulap Kota Lubuklinggau yang terbagi menjadi 3 (tiga) area kajian yaitu area kajian $\mathrm{A}$, area kajian $\mathrm{B}$, dan area kajian C. Pada Area Kajian A untuk strata tiang ditemukan 16 jenis. Rerata Indeks Nilai Penting dapat dilihat pada tabel 2.

Tabel 2. Rerata Indeks Nilai Penting (INP) Vegetasi StrataTiang pada Area kajian A

\begin{tabular}{llccr}
\hline No & Spesies & Nama Latin & Stand & $\begin{array}{c}\text { Rerata } \\
\text { INP }(\boldsymbol{\%})\end{array}$ \\
\hline $\mathbf{1}$ & ketapang & Terminalia catapa & $2,3,4,5,8,9,10$ & 85,87 \\
\hline $\mathbf{2}$ & belimbing & Averrhoa carambola & $2,3,5,7,9,10$ & 54,28 \\
\hline $\mathbf{3}$ & dadap & Eryhrina variegata & $1,3,8,10$ & 43,66 \\
\hline $\mathbf{4}$ & ara & Ficus carica & $4,5,8,9,10$ & 24,60 \\
\hline $\mathbf{5}$ & embacang & Mangifera foetida & 3,7 & 12,36 \\
\hline $\mathbf{6}$ & bintaro & Cerbera manghas & $3,7,9$ & 11,30 \\
\hline $\mathbf{7}$ & nangka & Artocarpus heterophyllus & 2,3 & 8,72 \\
\hline $\mathbf{8}$ & petai & Parkia speciosa & 2,7 & 8,23 \\
\hline $\mathbf{9}$ & jengkol & Archidendron pauciflorum & 7 & 4,76 \\
\hline $\mathbf{1 0}$ & pinang & Areca catechu & 3,9 & 3,68 \\
\hline $\mathbf{1 1}$ & jati & Tectoria grandis & 9 & 3,08 \\
\hline $\mathbf{1 2}$ & duku & Lansium domesticum & 4 & 2,92 \\
\hline $\mathbf{1 3}$ & rambutan & Nephelium lappaceum & 9 & 2,31 \\
\hline $\mathbf{1 4}$ & mangga & Mangifera foetida & 10 & 1,51 \\
\hline $\mathbf{1 5}$ & kemiri & Aleurites moluccanus & 3 & 1,42 \\
\hline $\mathbf{1 6}$ & pala & Myristica fragrans & 2 & \\
\hline
\end{tabular}

Berdasarkan tabel 2 pada area kajian A diperoleh 16 jenis strata tiang dengan nilai rerata Indeks Nilai Penting (INP) tertinggi yaitu Ketapang (Terminalia catapa) yang memiliki rerata Indeks Nilai Penting (INP) sebesar 85,87\% dan rerata Indeks Nilai Penting (INP) yang terendah pada area kajian A yaitu Pala (Myristica fragrans) dengan rerata Indeks Nilai Penting (INP) 1,29\%. Secara keseluruhan dari stand 1 - 10 pada area kajian A diperoleh nilai rerata Indeks Keanekaragaman ( $\mathrm{H}^{\prime}$ ) berada pada kisaran $\mathrm{H}^{\prime} 1 \leq \mathrm{H}^{\prime} \leq 3$ yaitu sebesar 1,01yang berarti bahwa keanekaragaman spesies strata Tiang pada area kajian A yaitu 
dalam kategori sedang melimpah. Nilai Indeks Keanekaragaman (H') pada area kajian A dapat dilihat pada tabel 3 berikut:

Tabel 3Nilai Indeks Keanekaragaman(H') Stara Tiang pada Area Kajian A

\begin{tabular}{ccl}
\hline STAND & NILAI H' & Keterangan \\
\hline $\mathbf{1}$ & 0,00 & Sedikit Melimpah \\
\hline $\mathbf{2}$ & 1,25 & Sedang melimpah \\
\hline $\mathbf{3}$ & 1,84 & Sedang melimpah \\
\hline $\mathbf{4}$ & 0,82 & Sedikit melimpah \\
\hline $\mathbf{5}$ & 0,97 & Sedikit melimpah \\
\hline $\mathbf{6}$ & 0,00 & Sedikit melimpah \\
\hline $\mathbf{7}$ & 1,37 & Sedang melimpah \\
\hline $\mathbf{8}$ & 1,04 & Sedang melimpah \\
\hline $\mathbf{9}$ & 1,75 & Sedang melimpah \\
\hline $\mathbf{1 0}$ & 1,01 & Sedang melimpah \\
\hline Jumlah & $\mathbf{1 0 , 0 5}$ & \\
\hline Rerata H' & $\mathbf{1 , 0 1}$ & Sedang melimpah \\
\hline
\end{tabular}

Hasil pengukuran faktor lingkungan abiotik pada area kajian A dapat dilihat pada tabel 4 berikut:

Tabel 4. Hasil Pengukuran Faktor Lingkungan Abiotik pada Area Kajian A

\begin{tabular}{|c|c|c|c|c|c|}
\hline $\begin{array}{c}\text { Area } \\
\text { Kajian }\end{array}$ & Waktu & $\begin{array}{c}\text { Suhu } \\
\text { Udara } \\
{ }^{0} \mathbf{C}\end{array}$ & $\begin{array}{c}\text { Kelembaban } \\
\text { Udara } \%\end{array}$ & $\underset{\text { tanah }}{\mathbf{p H}}$ & $\begin{array}{c}\text { Kelembaban } \\
\text { tanah }\end{array}$ \\
\hline \multirow[t]{3}{*}{ A } & $\begin{array}{l}\text { Pagi (06.00- } \\
10.00 \text { WIB) }\end{array}$ & 28,6 & 92,3 & 6,3 & 16 \\
\hline & $\begin{array}{l}\text { Siang (10.00- } \\
14.00 \text { WIB) }\end{array}$ & 29 & 92 & 6,6 & 10 \\
\hline & $\begin{array}{l}\text { Sore (14.00- } \\
18.00 \text { WIB) }\end{array}$ & 28,6 & 88 & 6,7 & 8 \\
\hline
\end{tabular}

Berdasarkan tabel 4 faktor abiotik lingkungan pada area kajian A dari waktu pagi sampai waktu sore tidak berbeda jauh. Suhu udara berkisar $28^{0} \mathrm{C}$ $29^{\circ} \mathrm{C}$ dengan kelembaban udara berkisar $88 \%$ - 92,3\% sedangkan kelembaban tanah $8-16$ dan $\mathrm{pH}$ tanah dalam keadaan asam $(6,3-6,7)$.Pada area kajian B, ditemukan 14 jenis strata tiang. Rerata Indeks Nilai Pneting dapat dilihat pada tabel 5. 
Tabel 5. Rerata Indeks Nilai Penting Vegetasi Strata Tiang pada Area kajian B

\begin{tabular}{|c|c|c|c|c|}
\hline No & Spesies & Nama Latin & Stand & $\begin{array}{c}\text { Rerata } \\
\text { INP }(\%)\end{array}$ \\
\hline 1 & Belimbing & Averrhoa carambola & $1,2,3,4,5,6,7,8,9,10$ & 80,90 \\
\hline 2 & Kopi & Coffea sp & $1,3,4,5,6,7,8,10$ & 70,84 \\
\hline 3 & Jati & Tectoria grandis & $2,3,4,5,7$ & 32,62 \\
\hline 4 & jeruk nipis & Citrus aurantiifolia & $4,9,10$ & 23,61 \\
\hline 5 & Flamboyan & Delonix regia & 1,24 & 20,72 \\
\hline 6 & Meranti & Shorea sp & $1,3,7$ & 17,84 \\
\hline 7 & jengkol & Myristica fragrans & $2,7,8$ & 11,76 \\
\hline 8 & ketapang & Terminalia catapa & 4,9 & 7,82 \\
\hline 9 & mangga & Mangifera indica & 6 & 6,16 \\
\hline 10 & ara & Ficus carica & 6 & 5,74 \\
\hline 11 & sengon & Albizia chinensis & 2 & 3,49 \\
\hline 12 & jambu air & Syzygium aquem & 9 & 2,46 \\
\hline 13 & pala & Myristica fragrans & 4 & 2,06 \\
\hline 14 & dadap & Erythrina variegata & 4 & 2,03 \\
\hline
\end{tabular}

Berdasarkan tabel 5 pada area kajian B diperoleh 14 jenis strata tiang dengan nilai rerata Indeks Nilai Penting (INP) tertinggi yaitu Belimbing (Averrhoa carambola) yang memiliki rerata Indeks Nilai Penting (INP) sebesar $80,90 \%$ dan rerata Indeks Nilai Penting (INP) yang terendah pada area kajian B yaitu Dadap (Erythrina variegata) dengan rerata Indeks Nilai Penting (INP) $2,03 \%$.

Secara keseluruhan dari stand 1 - 10 pada area kajian B diperoleh nilai rerata Indeks Keanekaragaman (H') berada pada kisaran H' > 1 yaitu sebesar 1,37 yang berarti bahwa keanekaragaman spesies strata tiang pada area kajian B yaitu dalam kategori sedang melimpah. Nilai Indeks Keanekaragaman (H') pada area kajian B dapat dilihat pada tabel 6 berikut:

Tabel 6. Nilai Indeks Keanekaragaman (H') Strata Tiang pada Area Kajian B

\begin{tabular}{ccl}
\hline STAND & NILAI H' & Keterangan \\
\hline $\mathbf{1}$ & 1,33 & Sedang Melimpah \\
\hline $\mathbf{2}$ & 1,57 & Sedang melimpah \\
\hline $\mathbf{3}$ & 1,00 & Sedang melimpah \\
\hline $\mathbf{4}$ & 1,93 & Sedang melimpah \\
\hline $\mathbf{5}$ & 1,01 & Sedang melimpah \\
\hline $\mathbf{6}$ & 1,34 & Sedang melimpah \\
\hline $\mathbf{7}$ & 1,57 & Sedang melimpah \\
\hline $\mathbf{8}$ & 0,84 & Sedikit melimpah \\
\hline $\mathbf{9}$ & 1,47 & Sedang melimpah \\
\hline $\mathbf{1 0}$ & 1,61 & Sedang melimpah \\
\hline Jumlah & $\mathbf{1 3 , 6 7}$ & \\
\hline Rerata H' & $\mathbf{1 , 3 7}$ & Sedang melimpah \\
\hline
\end{tabular}


Hasil pengukuran faktor lingkungan abiotik pada area kajian B dapat dilihat pada tabel 7 berikut:

Tabel 7.Hasil Pengukuran Faktor Lingkungan Abiotik pada Area Kajian B

\begin{tabular}{|c|c|c|c|c|c|}
\hline $\begin{array}{c}\text { Area } \\
\text { Kajian }\end{array}$ & Waktu & $\begin{array}{c}\text { Suhu } \\
\text { Udara } \\
{ }^{0} \mathrm{C}\end{array}$ & $\begin{array}{c}\text { Kelembaban } \\
\text { Udara \% }\end{array}$ & pH tanah & Kelembaban tanah \\
\hline \multirow{3}{*}{ B } & $\begin{array}{c}\text { Pagi } \\
(06.00- \\
10.00 \\
\text { WIB })\end{array}$ & 28,6 & 93 & 6,4 & 15 \\
\hline & $\begin{array}{c}\text { Siang } \\
(10.00- \\
14.00 \\
\text { WIB })\end{array}$ & 30 & 86 & 6,3 & 16 \\
\hline & $\begin{array}{c}\text { Sore } \\
(14.00- \\
18.00 \\
\text { WIB) }\end{array}$ & 28,3 & 92 & 6,7 & 10 \\
\hline
\end{tabular}

Berdasarkan tabel 7 faktor lingkungan abiotik pada area kajian B dari waktu pagi sampai waktu sore tidak berbeda jauh. Suhu udara berkisar $28,3^{\circ} \mathrm{C}$ $30^{\circ} \mathrm{C}$ dengan kelembaban udara berkisar $86 \%$ - 93\% sedangkan kelambaban tanah 10 - 16 dan $\mathrm{pH}$ tanah dalam keadaan asam $(6,3$ - 6,7).Pada area kajian c, ditemukan 24 jenis vegetasi strata tiang. Rerata indeks nilai penting dapat dilihat pada tabel 8.

Tabel 8. Rerata Indeks Nilai Penting (INP) Strata Tiang pada Area kajian C

\begin{tabular}{llllc}
\hline No & \multicolumn{1}{c}{ Spesies } & \multicolumn{1}{c}{ Nama Latin } & \multicolumn{1}{c}{ Stand } & $\begin{array}{c}\text { Rata-rata } \\
\text { INP (\%) }\end{array}$ \\
\hline $\mathbf{1}$ & Kopi & coffeasp & $2,3,4,7,8,9,10$ & 88,87 \\
\hline $\mathbf{2}$ & jambu air & Syzygium aquem & 4,5 & 17,83 \\
\hline $\mathbf{3}$ & Matoa & Pometia pinnata & 5 & 16,70 \\
\hline $\mathbf{4}$ & Belimbing & Averrhoacarambola & $2,3,4,7$ & 15,30 \\
\hline $\mathbf{5}$ & Jengkol & Archidendronjiringa & 1 & 11,56 \\
\hline $\mathbf{6}$ & Ketapang & Terminalia catapa & 3,4 & 10,60 \\
\hline $\mathbf{7}$ & Karet & Hevea bransiliensis & 7 & 10,20 \\
\hline $\mathbf{8}$ & Pulai & Aistoniascholaris & 1 & 9,25 \\
\hline $\mathbf{9}$ & Flamboyan & Delonixregia & 1 & 9,19 \\
\hline $\mathbf{1 0}$ & Pala & Myristica fragrans & 8 & 8,84 \\
\hline $\mathbf{1 1}$ & Durian & Durio zibethinus & 8 & 8,27 \\
\hline $\mathbf{1 2}$ & Merawan & Hopeamengarawan & 2 & 6,53 \\
\hline $\mathbf{1 3}$ & Petai & Parkia speciosa & 9 & 5,93 \\
\hline $\mathbf{1 4}$ & Duku & Lansium domesticum & 3,9 & 5,45 \\
\hline $\mathbf{1 5}$ & Gondang & Ficus variegat & 2 & 4,89 \\
\hline & & & & \\
\hline
\end{tabular}




\begin{tabular}{lllll}
\hline $\mathbf{1 6}$ & Embacang & Mangifera foetida & 3 & 4,70 \\
\hline $\mathbf{1 7}$ & Balam & Palaqium gutta & 3 & 4,62 \\
\hline $\mathbf{1 8}$ & Kelengkeng & Dimocarpus longan & 8 & 4,42 \\
\hline $\mathbf{1 9}$ & belimbing wuluh & Averrhoa carambola & 8 & 4,11 \\
\hline $\mathbf{2 0}$ & Nangka & Artocarpus heterophyllus & 4 & 3,58 \\
\hline $\mathbf{2 1}$ & Medang & Litsea firma & 2 & 3,22 \\
\hline $\mathbf{2 2}$ & Sirsak & Annona muricata & 9 & 2,85 \\
\hline $\mathbf{2 3}$ & Bayur & Pterospermum javanicum & 3 & 2,16 \\
\hline $\mathbf{2 4}$ & Jati & Tectoria grandis & 3 & 2,16 \\
\hline
\end{tabular}

Pada area kajian $\mathrm{C}$ berdasarakan tabel 8 diperoleh 24 jenis starta tiang dengan rerata Indeks Nilai Penting tertinggi yaitu Kopi (Coffea $s p$ ) yang memiliki Indeks Nilai Penting (INP) sebesar $88,87 \%$ dan rerata Indeks Nilai Penting terendah yaitu Jati (Tectona grandis) dan bayur (Pterospermum javanicum) dengan Indeks Nilai Penting (INP) sebesar 2,16\%.

Sedangkan nilai Indeks Keanekaragaman $\left(\mathrm{H}^{\prime}\right)$ pada area kajian $\mathrm{C}$ dapat dilihat pada Tabel 9 berikut:

Tabel 9. Nilai Indeks Keanekaragaman(H') pada Area Kajian C

\begin{tabular}{ccl}
\hline STAND & NILAI H' & Keterangan \\
\hline $\mathbf{1}$ & 1,10 & Sedang melimpah \\
\hline $\mathbf{2}$ & 1,30 & Sedang melimpah \\
\hline $\mathbf{3}$ & 1,99 & Sedang melimpah \\
\hline $\mathbf{4}$ & 1,51 & Sedang melimpah \\
\hline $\mathbf{5}$ & 0,69 & Sedikit melimpah \\
\hline $\mathbf{6}$ & 0,00 & Sedikit melimpah \\
\hline $\mathbf{7}$ & 1,10 & Sedang melimpah \\
\hline $\mathbf{8}$ & 1,46 & Sedang melimpah \\
\hline $\mathbf{9}$ & 0,94 & Sedikit melimpah \\
\hline $\mathbf{1 0}$ & 0,00 & Sedikit melimpah \\
\hline Jumlah & 10,09 & \\
\hline Rerata H' & 1,01 & Sedang melimpah \\
\hline
\end{tabular}

Berdasarkan Tabel 9 pada area kajian $\mathrm{C}$ diperoleh nilai Indeks Keanekaragaman ( $\left.\mathrm{H}^{\prime}\right)$ pada kisaran $\mathrm{H}^{\prime} 1 \leq \mathrm{H}^{\prime} \leq 3$ yang berarti pada stand tersebut termasuk dalam kategori sedang melimpah. Faktor lingkungan abiotik yang terukur pada area kajian $\mathrm{C}$ dapat dilihat pada Tabel 10 berikut ini:

Tabel 10. Hasil Pengukuran Faktor Lingkungan AbiotikPada Area Kajian C

\begin{tabular}{cccccc}
\hline \multirow{2}{*}{$\begin{array}{c}\text { Area } \\
\text { Kajian }\end{array}$} & Waktu & $\begin{array}{c}\text { Suhu } \\
\text { Udara } \\
\mathbf{0} \mathbf{C}\end{array}$ & $\begin{array}{c}\text { Kelembaban } \\
\text { Udara \% }\end{array}$ & $\begin{array}{c}\text { pH } \\
\text { tanah }\end{array}$ & $\begin{array}{c}\text { Kelembaban } \\
\text { tanah }\end{array}$ \\
\hline \multirow{2}{*}{$\mathbf{C}$} & Pagi (06.00-10.00 WIB) & 28,3 & 92,3 & 6,3 & 17 \\
\cline { 2 - 6 } & Siang (10.00-14.00 WIB) & 30 & 86 & 6,5 & 12 \\
\cline { 2 - 6 } & Sore (14.00-18.00 WIB) & 28,6 & 92,3 & 6,3 & 17 \\
\hline
\end{tabular}


Berdasarkan tabel 10 faktor lingkungan abiotik pada area kajian $\mathrm{B}$ dari waktu pagi sampai waktu sore tidak berbeda jauh. Suhu udara $28,3{ }^{\circ} \mathrm{C}-30^{\circ} \mathrm{C}$ dengan kelembaban udara 86\% - 92,3\% sedangkan kelambaban tanah 12 - 17 dan $\mathrm{pH}$ tanah dalam keadaan asam $(6,3-6,5)$.

\section{PEMBAHASAN}

Penelitian ini menggunakan metode tanpa plot (Plotless) yang berpusat pada titik (Point Centered Quarter Method). Metode Point Centered Quarter (PCQ) adalah metode pengukuran jarak yang dilakukan dari titik sampling ke tumbuhan (semak) dan dengan metode empat jarak diukur tiap-tiap titik sampling. Pada setiap titik dibuat empat kuadran (quarter) dengan membuat garis saling tegak lurus. Kemudian dirata-rata (Wiryono, 2012). Metode PCQ memiliki kelebihan dan kelemahan, dimana kelebihannya adalah dalam pelaksanaannya memerlukan waktu yang sedikit, mudah dan lebih cepat untuk mengetahui komposisi dan dominansi. Sedangkan kelemahannya adalah tidak dapat digunakan untuk populasi vegetasi yang pengelompokkannya tinggi atau menempati ruang secara seragam (Soegianto, 1994).

Berdasarkan hasil penelitian secara keseluruhan di Bukit Sulap Kota Lubuklinggau Area kajian A diperoleh 16 spesies strata tiang, Pada area kajian B diperoleh 14 spesies strata tiang,Sedangkan pada area kajian C ditemukan 24 spesies strata tiang. Pada area kajian A, spesies dengan INP tertinggi adalah ketapang (Terminalia catapa). Hal ini didukung oleh hasil penelitian Triyanti \& Arisandy (2018) di Bukit Sulap tentang vegetasi strata pancang yang menyatakan bahwa ketapang (Terminalia catapa) merupakan spesies yang paling tinggi INPnya. Menurut Thomson, et al (2006), ketapang cocok dengan iklim pesisir dan dataran rendah. Tumbuan ini bisa bertahan menghadapi bulan-bulan yang kering. Selain itu, Ketapang merupakan tanaman asli Asia Tenggara dengan tinggi mencapai 40 m. Pada area kajian B, belimbing merupakan spesies dengan INP tertinggi. Sedangkan pada area kajian C, kopi merupakan spesies yang memilik INP tertinggi. Menurut Aak (2006), kopi sangat baik tumbuh dengan tanah yang gembur, subur, banyak humus. Selain itu, kopi tumbuh pada pH 5,5 sampai dengan 6,5. Hal ini sesuai dengan faktor abiotik yang telah diukur.

Masing-masing stand pada setiap area kajian diperoleh Indeks Keanekaragaman $\left(\mathrm{H}^{\prime}\right)$ yang berfungsi untuk memperlihatkan seberapa melimpah tingkat keanekaragaman spesies pada masing-masing stand tiap area kajian. Berdasarkan hasil penelitian diketahui bahwa area kajian $\mathrm{C}$ mempunyai jumlah vegetasi paling banyak, sedangkan area kajian B memiliki jumlah paling sedikit. Area kajian B mempunyai nilai rerata Indeks Keanekaragaman (H') strata tiang yang paling tinggi yaitu 1,37, sedangkan yang menempati urutan terendah adalah area kajian A,B dengan rerata Indeks Keanekaragaman (H') 1,01. Area kajian dalam penelitian ini memiliki Indeks Keanekaragaman yang sedang melimpah karena menurut Shannon-Wiener dalam Fachrul (2012) jika $H^{\prime} 1 \leq H^{\prime} \leq 3$ 
menunjukkan bahwa keanekaragaman spesies pada daerah tersebut adalah sedang melimpah. Hal ini menunjukkan bahwa keadaan tumbuhan strata tiang yang terdapat Bukit Sulap Kota Lubuklinggau memiliki produktivitas sedang, sehingga keanekaragaman strata tiang masih dalam keadaan seimbang atau masih dalam keadaan stabil. Seperti yang dikemukakan oleh Indriyanto (2012), keanekaragaman jenis suatu komunitas dikatakan tinggi jika komunitas itu disusun oleh banyak spesies. Sebaliknya suatu komunitas dikatakan memiliki keanekaragaman spesies yang rendah jika komunitas itu disusun oleh sedikit spesies dan jika hanya sedikit spesies yang dominan.

Dalam skala besar, suhu sebagai komponen iklim mempengaruhi tipe hutan. Dalam skala kecil, suhu di suatu tempat mempengaruhi tumbuhan yang hidup di tempat itu. Proses fisiologis tumbuhan dipengaruhi oleh suhu, namun sulit untuk menentukan suhu optimal untuk pertumbuhan tanaman karena tahapan perkembangan yang berbeda membutuhkan suhu yang berbeda pula (Wiryono, 2012). Suhu udara Bukit Sulap Kota Lubuklinggau berkisar $28,6^{\circ} \mathrm{C}-30^{\circ} \mathrm{C}$ dengan kelembaban udara berkisar 86\% - 93\%. Menurut Wiryono (2012) sebagian besar tumbuh-tumbuhan di ekosistem tumbuh di atas tanah sehingga sifat tanah sangat mempengaruhi tumbuh-tumbuhan. Faktor iklim tanah diantaranya yaitu kelembaban tanah dan derajat keasaman $(\mathrm{pH})$ tanah. Kelembaban tanah berkisar 8 - 17. Menurut Agustina (2004:27) derajat keasaman (pH) tanah optimum untuk pertumbuhan sebagian besar tanaman berkisar pada derajat keasaman $(\mathrm{pH})$ tanah 6 - 6,5 sedangkan derajat keasaman $(\mathrm{pH})$ tanah berkisar 6,3 - 6,7. Dengan demikian faktor abiotik di Bukit Sulap Kota Lubuklinggau mendukung untuk pertumbuhan sebagian besar tumbuhan yang ada di Bukit Sulap Kota Lubuklinggau.

\section{SIMPULAN}

Berdasarkan penelitian yang telah dilakukan, dapat disimpulkan bahwa rerata Indeks Nilai Penting (INP) terbesar pada strata Tiang di area kajian A,B, dan $\mathrm{C}$ berturut-turut adalah ketapang $(85,87 \%)$, belimbing $(80,90 \%)$, dan kopi $(88,87 \%)$. Sedangkan faktor lingkungan abiotik yang terukur adalah Suhu udara di Bukit Sulap Kota Lubuklinggau berkisar $28,3^{\circ} \mathrm{C}-30^{\circ} \mathrm{C}$ dengan kelembaban udara $86 \%-93 \%$. Kelembaban tanah berkisar $8-17$ sedangkan derajat keasaman $(\mathrm{pH})$ tanah berkisar 6,3-6,7.

\section{DAFTAR PUSTAKA}

Aak. (2006). Budi daya Tanamn Kopi. Yogyakarta: Kanisius.

Arikunto. (2010). Prosedur Penelitian Suatu Pendekatan Praktik.Jakarta: Rineka Cipta.

Fachrul, M. F. (2012). Metode Sampling Bioekologi. Jakarta: PT Bumi Aksara. Hidayati, N. \& Retnowati, D. (2010). Kamus Lengkap Biologi. Dwimedia Comp. Indriyanto. (2008). Ekologi Hutan.Jakarta: Bumi Aksara.. 
Indrawan M, Primack R.,B \& Supriatna, J. (2007). Biologi Konservasi. Jakarta; Yayasan Obor Indonesia.

Kausar. (2010). Konflik Kepentingan Dibalik Konservasi Studi di Taman Nasional Kerinci Sebelat (TNKS) Provinsi Jambi.IndonesiaJournal of Agricultural Economics (IJAE). 2 (1):134.

Sunarya, A. (2016). Bukit Sulap. Lubuklinggau: Balai Besar TNKS.

Soegianto, A. (1994). Ekologi Kuantitatif. Surabaya: Usaha Nasional.

Thomson, L.,A.,J \& Evans, B. (2006). Terminalia catappa (tropical almond) Species Profiles for Pacific Island. Italy: South Pacific Regional Initiative of Forest Genetic Resources.

Triyanti, M \& Arisandy, D.A. (2018). Analisis vegetasi strata pancang di Bukit Sulap Kota lubuklinggau. Prosiding National Conference on Mathematics, Science, and Education (NACOMSE). Pamekasan.

Wiryono. (2012). Ekologi Hutan. Bengkulu: UNIB Press. 